\title{
Vitamin D status and body composition: a cross-sectional study among employees at a private university in Lebanon
}

Sibelle Al Hayek ${ }^{1,2}$, Jocelyne Matar Bou Mosleh², Rachelle Ghadieh ${ }^{2,3}$ and Jessy El Hayek Fares²*

\begin{abstract}
Background: The prevalence of low vitamin D status is increasing globally, and Lebanon is not spared. The objectives of this study are to determine the prevalence and correlates of low vitamin D status, and to assess the association between percent body fat and vitamin D status, independently of obesity.

Methods: A cross-sectional study was performed on NDU employees. Data on dietary intake, physical activity, lifestyle, health status, and demographic variables were collected during a face-to-face interview. Anthropometric measures (weight, height and waist circumference) were measured and body composition was assessed using the bioelectrical impedance analysis (BIA) machine InBody 720 (Biospace, Seoul, Korea). The Nutritionist Pro diet analysis software version 31.0 was used to estimate dietary intake of vitamin D. Serum 25 hydroxyvitamin D (25(OH)D) was measured using enzyme linked immunosorbent assay kit (ELISA) (Calbiotech, Spring Valley, California, USA). Vitamin D status was assessed according to the National Osteoporosis Foundation (sufficiency: $\geq 75 \mathrm{nmol} / \mathrm{L} / \geq 30 \mathrm{ng} / \mathrm{mL}$ ) and the Institute of Medicine cut-offs (adequacy: $\geq 50 \mathrm{nmol} / \mathrm{L} / \geq 20 \mathrm{ng} / \mathrm{mL}$ ). Statistical analyses were performed by SPSS version 22.
\end{abstract}

Results: A total of 344 employees (50\% Male) aged between 20 and 74 years participated in the study. More than half of the participants were overweight and obese. Mean serum vitamin D concentrations were $28.2 \pm 13.9 \mathrm{ng} / \mathrm{mL}$. Among participants, $37.5 \%$ of our study population had $25(\mathrm{OH}) \mathrm{D} \geq 30 \mathrm{ng} / \mathrm{mL}$, and $68.3 \%$ had $25(\mathrm{OH}) \mathrm{D} \geq 20 \mathrm{ng} / \mathrm{mL}$. Individuals with low vitamin D status had significantly higher percent body fat (PBF) $(p<0.005)$, and higher waist circumference (WC) ( $p=0.012)$ than in the sufficient group, however BMI did not differ by vitamin D status. Logistic regression analysis indicated that a $1 \%$ increase in body fat increases the odds of having $25(\mathrm{OH}) \mathrm{D} \leq 30 \mathrm{ng} / \mathrm{mL}$ by $8 \%$ while controlling for $\mathrm{BMI}$ and other confounders $(p=0.019)$.

Conclusion: This study reinforces the need for regular screening for low vitamin D status in Lebanese adults, particularly individuals at risk, including those with high risk WC, high PBF, who work indoors and have low vitamin D intake, and recommending vitamin D supplementation if needed.

Keywords: Vitamin D status, Vitamin D intake, Percent body fat, Lebanese, Body composition, Adults

\footnotetext{
* Correspondence: jelhayek@ndu.edu.lb

${ }^{2}$ Department of Nursing and Health Sciences, Notre Dame University-

Louaize (NDU), Zouk Mosbeh, Lebanon

Full list of author information is available at the end of the article
}

(c) The Author(s). 2018 Open Access This article is distributed under the terms of the Creative Commons Attribution 4.0 International License (http://creativecommons.org/licenses/by/4.0/), which permits unrestricted use, distribution, and reproduction in any medium, provided you give appropriate credit to the original author(s) and the source, provide a link to the Creative Commons license, and indicate if changes were made. The Creative Commons Public Domain Dedication waiver (http://creativecommons.org/publicdomain/zero/1.0/) applies to the data made available in this article, unless otherwise stated. 


\section{Background}

Vitamin D is a fat soluble compound that can be obtained from two sources: primarily sunlight exposure and diet (e.g: fatty fish, egg yolk, cod-liver, fortified foods, and supplements) [1]. Vitamin D refers to vitamin $\mathrm{D}_{2}$ (ergocalciferol) or vitamin $\mathrm{D}_{3}$ (cholecalciferol) [1]

Measurement of serum 25 hydroxyvitamin D $(25(\mathrm{OH}) \mathrm{D})$ concentration is the best indicator to assess vitamin $\mathrm{D}$ status, since it indicates both endogenous production and dietary vitamin $\mathrm{D}$ intake. The Institute of Medicine (IOM) recommends concentrations of $25(\mathrm{OH}) \mathrm{D}$ to be $\geq 20 \mathrm{ng} / \mathrm{mL}$ ( $\geq 50 \mathrm{nmol} / \mathrm{L}$ ) [2], while other institutes, such as the National Osteoporosis Foundation (NOF) and the American Geriatrics Society (AGS) recommend concentrations of $25(\mathrm{OH}) \mathrm{D}$ to be $>30 \mathrm{ng} / \mathrm{mL}$ (> $75 \mathrm{nmol} / \mathrm{L}$ ) [3]. The inconsistency in the definition of healthy vitamin D status depends mainly on the health outcome considered.

The prevalence of low vitamin $\mathrm{D}$ status is increasing globally. Levels of $25(\mathrm{OH}) \mathrm{D}<10 \mathrm{ng} / \mathrm{mL}$ in adults were most common in Asia (78\%), compared to Europe (2-30\%), and North America (13\%) [4]. Despite the sunny weather in Lebanon, multiple studies have reported a high prevalence of low vitamin D status in the Lebanese population. For instance, Hoteit et al., 2014 reported that $60 \%$ of Lebanese adults had $25(\mathrm{OH}) \mathrm{D}<20 \mathrm{ng} / \mathrm{mL}$ [5], while Rachkidi and Aoun, 2015 reported a higher prevalence of low vitamin D status among ambulatory patients (73.33\%), using a higher cutoff $(25(\mathrm{OH}) \mathrm{D}<30 \mathrm{ng} / \mathrm{mL}),[6]$.

Low serum vitamin $\mathrm{D}$ concentrations have been reported among obese individuals [7]. The high prevalence of low vitamin D status paralleled the pandemic of obesity [8]. Both conditions, obesity and low vitamin D status, have been implicated in the development of many chronic diseases including type 2 diabetes, cancer, and cardiovascular diseases [9]. Accordingly, more research is focusing on the understanding of the relationship between vitamin D status and obesity [8]. Studies in the Middle East assessing this relationship are limited [10-12], even though many countries in the Middle East reported high prevalence rates of low vitamin D status and obesity $[5,9,13]$. Gannage et al., 2010 showed that 25(OH)D was inversely correlated with BMI $(r=-0.18 ; p<0.01)$ and WC $(r=-$ $0.19 ; \mathrm{p}<0.01)$ among 381 Lebanese non-obese university students. However, these results do not necessarily apply to overweight and obese individuals in older age groups, who are at higher risk of chronic disease [14]. Even though the association between serum 25(OH)D levels and percent body fat (PBF) has been explored in the literature, this association has only been explored in the Arab region in Emirati obese diabetic adults. One cross-sectional study among 309 obese diabetic adults (age range: 3060 years) in UAE showed that the prevalence of
$25(\mathrm{OH}) \mathrm{D}<50 \mathrm{nmol} / \mathrm{L}$ was $83.2 \%$. Furthermore, serum $25(\mathrm{OH}) \mathrm{D}$ correlated negatively with body mass index (BMI) $(r=-0.15, p<0.05)$, waist circumference (WC) $(r=-0.17, \mathrm{p}<0.05)$, and fat mass $(r=-0.16, \mathrm{p}<0.05)$ [10]. The results of this study cannot be generalized to the general population, as the study participants were diabetic and obese, and the relationship between vitamin $\mathrm{D}$ status and obesity could be altered by diabetes. In other regions across the world, the results of studies on the association between serum 25(OH)D levels and PBF were inconsistent. This controversy in the literature could be due to the fact that the correlates and confounders (vitamin D intake, sun exposure, sunscreen use, age, etc.) affecting the relationship between vitamin $\mathrm{D}$ status and percentage body fat (PBF) were not assessed thoroughly. Further, the association between obesity and vitamin D status could also differ between gender and among different ethnic groups [15-17]. There is a substantial body of evidence supporting a genetic basis for low 25(OH)D concentrations in the Middle East. It has been shown previously that people from the Middle Eastern region have a specific phenotype that exposes them to low vitamin D status [18]. Therefore, the independent association between vitamin D status and PBF still needs further examination.

Accordingly, our objectives were to examine the association of socio-demographic, lifestyle, dietary, and anthropometric factors with vitamin D status, and to assess the independent association between PBF and vitamin D status among university employees in Lebanon. We hypothesized that people with higher total PBF will have lower serum vitamin D concentrations, independent of BMI.

To our knowledge, this study is the first to assess the association between serum 25(OH)D concentrations and PBF in Lebanon.

\section{Methods \\ Study design and recruitment methods}

A cross-sectional study was carried out on Notre Dame University (NDU) employees, in the Zouk Mosbeh, North, and Shouf campuses. Prior to the initiation of the study, the study protocol was approved by the Institutional Review Board of NDU.

Beginning in October 2016, an e-invite was sent to all staff and faculty members of NDU to invite them to participate in the study. Following the e-invite, four nutritionists visited all faculty and staff members in their offices to encourage participation. Of the 600 contacted employees in the three NDU campuses, 360 accepted to participate and were screened for eligibility. Exclusion criteria included pregnancy, lactation, failure to complete the questionnaires, and presence of a pacemaker or metal pieces in the participant's body. Those who were found to be eligible $(n=344)$ 
were asked to sign an informed consent form and then contacted by the study investigators to arrange for a 30-min face-to-face interview. An identification number was assigned to each participant. All questionnaires were labeled using codes. The investigators maintained the list associating names with codes and were in charge of keeping it confidential.

\section{Data collection procedures}

During the 30-min face-to-face interview, trained nutritionists filled out three questionnaires (background questionnaire, short-form of the International Physical Activity Questionnaire [IPAQ-short form] and food frequency questionnaire [FFQ]). All questionnaires were pre-tested using a sample of thirty NDU employees in the three campuses. Revisions and corrections were performed before initializing the study. The background questionnaire assessed demographic (i.e income, age, gender, marital status, etc.) and lifestyle variables (i.e sun exposure practices, sunscreen use, smoking, alcohol intake, etc.). The IPAQ-short form was used to assess the level of physical activity. IPAQ asks about three specific types of activities: walking, moderate and vigorous physical activities and, time spent by an individual [19]. The items were structured to provide separate scores on each of these activities. Using the following values, Walking = 3.3 METs, Moderate PA = 4.0 METs and Vigorous PA = 8.0 METs, four continuous scores were calculated. These scores were then added to calculate the total physical activity score. Low-level, moderate-level and high-level PA were defined by scores of less than 600 MET-minutes per week, between 600 to less than 3000 MET-minutes per week, and of 3000 or more MET-minutes per week, respectively. The FFQ was comprised of 9 food items. For each food item, participants were asked to mark their frequency of intake of a designated serving/portion size per day/week/month or rarely/never during the past year. The FFQ included full-fat/low-fat dairy products, eggs and egg-based dishes, fish, margarine, cheeses, and ice cream. Dietary intake of vitamin D was assessed using an adapted version of an existing prototype food frequency questionnaire specific for assessment of vitamin D intake that was developed by study investigators [20]. The Nutritionist Pro diet analysis software, version 31.0 (Axxya Systems, Woodinville, WA, USA) was used to generate estimates of dietary intake of vitamin D [2123]. Lebanese dishes and recipes were composed and entered using this software according to the Middle-East Food Composition Tables and the Canadian Nutrient File [23]. At the end of the interview, study participants were invited to the nutrition laboratory to collect anthropometric (height, WC, weight and body composition) and biochemical measurements after an overnight fast. Height was measured to the nearest $0.1 \mathrm{~cm}$ according to the following protocol: no shoes, heels together, and head touching the stadiometer's ruler aligned horizontally. For WC measurement, a non-stretchable tailor measuring tape was placed around the bare abdomen just above the hip bone and parallel to the floor. Participants were asked to exhale, and measurement was taken to the nearest centimeter at the midpoint between the bottom of the rib cage and above the top of the iliac crest during minimal respiration. WC values were classified as high risk/low risk for diseases, using the World Health Organization (WHO) cutoffs for men $>102 \mathrm{~cm}$ and women $>88 \mathrm{~cm}$ [24]. Weight and body composition were assessed using the bioelectrical impedance analysis (BIA) machine InBody 720 (Biospace, Seoul, Korea). BIA is widely used in research; it is quick, safe, and inexpensive [25]. BIA measures body water, then estimates fat mass and fat-free mass [26]. The BIA machine was transported to different campuses for data collection, and it was calibrated prior to its use. The participants were asked to stand on the machine barefooted, without wearing any metal/jewelry, after wiping hands and feet with electrolyte wipes. BMI was calculated as: Weight $(\mathrm{kg}) /$ Height $\left(\mathrm{m}^{2}\right)$. Underweight was defined as BMI $<18.5 \mathrm{~kg} / \mathrm{m}^{2}$, normal weight: $18.5-24.9 \mathrm{~kg} / \mathrm{m}^{2}$, overweight: $25-29.9 \mathrm{~kg} / \mathrm{m}^{2}$, and obese $\geq 30 \mathrm{~kg} / \mathrm{m}^{2}$ [24].

Upon the visit to the nutrition laboratory, a nurse collected a fasting sample of blood. Samples collected at the regional campuses were transported to the Zouk Mosbeh campus on ice. Samples were stored at $-20{ }^{\circ} \mathrm{C}$ in the freezer for a maximum of 6 weeks before analysis. Serum 25(OH)D concentrations were measured at the Biology laboratory at NDU Zouk Mosbeh campus using enzyme linked immunosorbent assay kit (ELISA) (Calbiotech, Spring Valley, California, USA), with an intra-assay coefficient variation of $4.95 \%$ and an inter-assay coefficient variation of $5.63 \%$, and a sensitivity of $0.67 \mathrm{ng} / \mathrm{mL}$.

Since there are no universal cutoff values for categorizing vitamin D status, serum $25(\mathrm{OH}) \mathrm{D}$ concentration was compared to different cutoffs, specifically the Institute of Medicine (IOM) and National Osteoporosis Foundation (NOF). According to the IOM, serum 25(OH)D concentrations less than $12 \mathrm{ng} / \mathrm{mL}(<30 \mathrm{nmol} / \mathrm{L})$ are associated with vitamin $\mathrm{D}$ deficiency, concentrations between 12 to less than $20 \mathrm{ng} / \mathrm{mL}$ ( 30 to $<50 \mathrm{nmol} / \mathrm{L}$ ) are generally considered inadequate for bone and overall health in healthy individuals, and serum $25(\mathrm{OH}) \mathrm{D} \geq 20 \mathrm{ng} / \mathrm{mL}$ $(\geq 50 \mathrm{nmol} / \mathrm{L})$ concentrations are considered adequate [2]. However, the National Osteoporosis Foundation (NOF) classifies the vitamin D status as deficient if serum $25(\mathrm{OH}) \mathrm{D}$ levels are $\leq 20 \mathrm{ng} / \mathrm{mL}$ $(\leq 50 \mathrm{nmol} / \mathrm{L})$, insufficient if levels are $>20-30 \mathrm{ng} /$ $\mathrm{mL}(>50-75 \mathrm{nmol} / \mathrm{L})$, and sufficient if levels are $>$ $30 \mathrm{ng} / \mathrm{mL}$ (> $75 \mathrm{nmol} / \mathrm{L})$ [3]. 


\section{Statistical analyses}

Assuming that the prevalence rate of vitamin D deficiency among Lebanese adults was 73\% [5], the sample size was calculated to be 303 individuals. Quantitative and qualitative measurements were summarized as mean \pm standard deviation and $\mathrm{n}(\%)$, respectively. Comparisons of continuous and categorical variables were performed using independent sample $\mathrm{T}$ Test/Mann-Whitney-U-test and the chi square test /Fisher's exact test, respectively. Two logistic regression models were used, where low vitamin $\mathrm{D}$ status (defined as $25(\mathrm{OH}) \mathrm{D} \leq 30 \mathrm{ng} / \mathrm{mL}$ or $\leq 20 \mathrm{ng} / \mathrm{mL}$ ) was used as the dependent variable and PBF was used as the independent variable, controlling for BMI, age, gender, sunlight exposure, vitamin D intake, vitamin D supplements use, alcohol intake, intake of oral contraceptive pills (OCP), education, sunscreen use, chronic illness status, income, physical activity, cholesterol, triglycerides, HDL, and LDL levels. Statistical analyses were performed using the Statistical Package for Social Sciences (SPSS) version 22 for Windows. A $p$-value of less than 0.05 was considered statistically significant.

\section{Results}

A total of 344 subjects ( $50 \%$ men and $50 \%$ women) aged between 20 and 74 years participated in the study. Characteristics of the study population stratified by gender are summarized in Table 1. The sample consisted mostly of educated participants holding a university degree (78.2\%), married (65.4\%), with an income of less than $\$ 4000$ per month (57.9\%). The majority of study participants were non-smokers (61.6\%) and did not drink alcohol (74.1\%). More than half of the participants (64.2\%) had a low level of physical activity. Daily mean vitamin D intake was 2.2 $\pm 3.2 \mu \mathrm{g}$. Of the participants, $21.5 \%$ were taking vitamin $\mathrm{D}$ supplements. More than one third of the participants were of a healthy weight (35.5\%), while the majority of participants were overweight and obese (64.0\%). Men were older, had lower PBF, had a higher milk intake, reported higher prevalence of medical morbidities, smoking and drinking, overweight and obesity, spending $>60$ mins in the sun, and hypertriglyceridemia compared to women $(p<0.005)$. However, men had a lower prevalence of sunscreen use $(4.1 \%)$ compared to women $(54.1 \%, \mathrm{p}<0.005)$.

In the total sample, mean vitamin $\mathrm{D}$ serum concentration was $28.2 \pm 13.9 \mathrm{ng} / \mathrm{mL}$. There were no significant differences between genders. Among study participants, $37.5 \%$ had serum $25(\mathrm{OH}) \mathrm{D}$ concentrations $\geq 30 \mathrm{ng} / \mathrm{mL}, 31.7 \%$ had serum $25(\mathrm{OH}) \mathrm{D}$ concentrations $<20 \mathrm{ng} / \mathrm{mL}$. Further, 9.7\% of participants had 25(OH)D concentrations $<12 \mathrm{ng} / \mathrm{mL}$. There was no significant difference in vitamin $\mathrm{D}$ status between men and women (Figs. 1 and 2).

The associations of socio-demographic, dietary, lifestyle, and anthropometric factors with insufficient/sufficient vitamin D status (defined as $25(\mathrm{OH}) \mathrm{D} \leq$ or $>30 \mathrm{ng} / \mathrm{ml}$ ) were presented in Table 2. In the total sample, vitamin D intake, sun exposure, $\mathrm{PBF}$, and $\mathrm{WC}$ were associated with vitamin D status. Individuals with sufficient vitamin D status had higher vitamin D intake $(3.3 \pm 5.7 \mu \mathrm{g})$ than in the insufficient group $(1.9 \pm 2.0 \mu \mathrm{g})(p=0.047)$. A higher percentage $(41.0 \%)$ of those spending $>60$ mins of daily sun exposure had sufficient vitamin D status compared to those spending $\leq 15$ mins $(21.4 \%, p=0.005)$. Among all participants, the mean PBF was lower in those having sufficient vitamin D status $(27.2 \pm 7.5 \%)$ compared to those having insufficient status $(31.2 \pm 7.5 \%, p<0.005)$. Among individuals having high risk WC, only $20.3 \%$ had sufficient vitamin D status while $79.7 \%$ had insufficient vitamin D status $(p=0.012)$. In men, only sun exposure and PBF were associated with vitamin D status. A higher percentage $(42.6 \%)$ of those spending $>60$ mins of daily sun exposure had sufficient vitamin D status compared to those spending $\leq 15$ mins $(20.4 \%, p=0.028)$. In men, the mean PBF was lower in those having sufficient vitamin D status $(25.6 \pm 7.5 \%)$ compared to those having insufficient status $(28.3 \pm 6.6 \%, p=0.039)$. In women, vitamin $\mathrm{D}$ intake, alcohol intake, BMI, PBF, and WC were associated with vitamin $\mathrm{D}$ status. Individuals with sufficient vitamin $\mathrm{D}$ status (>30 ng/mL) had higher mean vitamin $\mathrm{D}$ intake $(3.1 \pm 2.7 \mu \mathrm{g})$ than in the insufficient group (1.6 $\pm 1.7 \mu \mathrm{g})(p=0.006)$. Among female alcohol drinkers, $45.8 \%$ had sufficient vitamin D status compared to $20.6 \%$ of female alcohol non-drinkers $(p=0.022)$. Among obese women, 95.0\% had insufficient vitamin D status, while only $5.0 \%$ had sufficient vitamin D status $(p=0.008)$. In women, the mean PBF was lower in those having sufficient vitamin D status $(29.3 \pm$ 7.0\%) compared to those having insufficient status $(34.4 \pm 7.0 \%, p=0.001)$. Among women having high risk WC, $87.1 \%$ had insufficient vitamin D status, while only $12.9 \%$ had sufficient vitamin D status $(p=0.003)$.

Socio-demographic, dietary, lifestyle, and anthropometric factors were not associated with adequate/inadequate vitamin D status (defined as $25(\mathrm{OH}) \mathrm{D}<$ or $\geq 20 \mathrm{ng} / \mathrm{ml}$ ) (Data not shown).

Using multiple logistic regression analysis to examine the association between body composition and insufficient vitamin D status (defined as $25(\mathrm{OHD} \leq 30 \mathrm{ng} / \mathrm{mL}$ ), it was found that for each $1 \%$ increase in body fat, participants were around $8 \%$ more likely to have insufficient vitamin D status $(p=0.019)$ while controlling for BMI, age, gender, education, sunscreen use, vitamin D intake, intake of vitamin D supplements, medical condition, sunlight exposure, and intake of OCPs (Table 3). Using multiple logistic regression analysis to examine the association between body composition and inadequate vitamin D status (defined as $25(\mathrm{OHD}<20 \mathrm{ng} / \mathrm{mL}$ ), it was shown that for each $1 \%$ increase in body fat, participants were around $6 \%$ more likely to have inadequate 
Table 1 Sample Characteristics (Socio-demographic, Dietary, Lifestyle, Anthropometric, and Biochemical factors) of Study Participants

\begin{tabular}{|c|c|c|c|c|c|c|c|}
\hline \multirow[t]{2}{*}{ Characteristic } & \multicolumn{2}{|l|}{ Total $(n=344)$} & \multicolumn{2}{|c|}{ Men $(n=172)$} & \multicolumn{2}{|c|}{ Women $(n=172)$} & \multirow[t]{2}{*}{$P$-value ${ }^{4}$} \\
\hline & $\mathrm{n}$ or mean or median & $\%$ or $\mathrm{SD}$ or $\mathrm{IQR}$ & $\mathrm{n}$ or mean & $\%$ or SD & $\mathrm{n}$ or mean & $\%$ or SD & \\
\hline Age (years) & 42.6 & 11.5 & 45.6 & 12.1 & 39.5 & 10.2 & 0.000 \\
\hline \multicolumn{8}{|l|}{ Marital status } \\
\hline Single/ Separated/ Divorced & 119 & 34.6 & 53 & 30.8 & 66 & 38.4 & \multirow[t]{2}{*}{0.174} \\
\hline Married & 225 & 65.4 & 119 & 69.2 & 106 & 61.6 & \\
\hline \multicolumn{8}{|l|}{ Education level } \\
\hline High school & 75 & 21.8 & 48 & $27.9^{\mathrm{a}}$ & 27 & $15.7^{\mathrm{b}}$ & \multirow[t]{3}{*}{0.013} \\
\hline Bachelor degree & 87 & 25.3 & 36 & $20.9^{\mathrm{a}}$ & 51 & $29.6^{a}$ & \\
\hline Graduate & 182 & 52.9 & 88 & $51.2^{\mathrm{a}}$ & 94 & $54.7^{\mathrm{a}}$ & \\
\hline \multicolumn{8}{|l|}{ Income (\$) } \\
\hline$<2250$ & 112 & 32.6 & 61 & $35.5^{\mathrm{a}}$ & 51 & $29.6^{a}$ & \multirow[t]{3}{*}{0.033} \\
\hline $2250-4000$ & 87 & 25.3 & 33 & $19.2^{\mathrm{a}}$ & 54 & $31.4^{\mathrm{b}}$ & \\
\hline$>4000$ & 145 & 42.2 & 78 & $45.3^{\mathrm{a}}$ & 67 & $39.0^{\mathrm{a}}$ & \\
\hline \multicolumn{8}{|l|}{ Medical morbidity } \\
\hline No & 202 & 58.9 & 91 & 53.2 & 111 & 64.5 & \multirow[t]{2}{*}{0.043} \\
\hline Yes & 141 & 41.1 & 80 & 46.8 & 61 & 35.5 & \\
\hline Vitamin D intake $(\mu \mathrm{g})$ & 1.3 & {$[0.6-3.2]$} & 2.5 & 4.0 & 2.0 & 2.0 & 0.209 \\
\hline \multicolumn{8}{|c|}{ Intake of vitamin D supplement, past 3 months } \\
\hline No & 270 & 78.5 & 142 & 82.6 & 128 & 74.4 & \multirow[t]{2}{*}{0.088} \\
\hline Yes & 74 & 21.5 & 30 & 17.4 & 44 & 25.6 & \\
\hline \multicolumn{8}{|l|}{ Alcohol drinking } \\
\hline No & 255 & 74.1 & 112 & 65.1 & 143 & 83.1 & \multirow[t]{2}{*}{0.000} \\
\hline Yes & 89 & 25.9 & 60 & 34.9 & 29 & 16.9 & \\
\hline \multicolumn{8}{|l|}{ Smoking } \\
\hline No & 212 & 61.6 & 93 & 54.1 & 119 & 69.2 & \multirow[t]{2}{*}{0.006} \\
\hline Yes & 132 & 38.4 & 79 & 45.9 & 53 & 30.8 & \\
\hline \multicolumn{3}{|l|}{ Daily exposure to direct sunlight } & & & & & \multirow[t]{4}{*}{0.008} \\
\hline$\leq 15$ mins & 136 & 39.5 & 66 & $38.4^{\mathrm{a}}$ & 70 & $40.7^{\mathrm{a}}$ & \\
\hline $16-60 \mathrm{~min}$ & 112 & 32.6 & 46 & $26.7^{\mathrm{a}}$ & 66 & $38.4^{\mathrm{b}}$ & \\
\hline$>60$ mins & 96 & 27.9 & 60 & $34.9^{\mathrm{a}}$ & 36 & $20.9^{b}$ & \\
\hline \multicolumn{8}{|l|}{ Use sunscreen } \\
\hline No & 244 & 70.9 & 165 & 95.9 & 79 & 45.9 & \multirow[t]{2}{*}{0.000} \\
\hline Yes & 100 & 29.1 & 7 & 4.1 & 93 & 54.1 & \\
\hline Physical activity level & & & & & & & \\
\hline Low & 221 & 64.2 & 10.3 & 59.9 & 118 & 68.6 & 0.115 \\
\hline Moderate/High & 123 & 35.8 & 69.0 & 40.1 & 54 & 31.4 & \\
\hline OCP ${ }^{1}$ use & & & & & & & \\
\hline No & 341 & 99.1 & 100 & 100 & 169 & 98.3 & 0.248 \\
\hline Yes & 3 & 0.9 & 0 & 0 & 3 & 1.7 & \\
\hline$B M I^{2}$ & & & & & & & \\
\hline Underweight & 2 & 0.6 & 0 & $0.0^{\mathrm{a}, \mathrm{b}}$ & 2 & $1.2^{\mathrm{a}, \mathrm{b}}$ & 0.000 \\
\hline Normal & 122 & 35.5 & 27 & $15.7^{\mathrm{a}}$ & 95 & $55.2^{\mathrm{b}}$ & \\
\hline Overweight & 130 & 37.8 & 86 & $50.0^{\mathrm{a}}$ & 44 & $25.6^{\mathrm{b}}$ & \\
\hline Obese & 90 & 26.2 & 59 & $34.3^{\mathrm{a}}$ & 31 & $18.0^{\mathrm{b}}$ & \\
\hline
\end{tabular}


Table 1 Sample Characteristics (Socio-demographic, Dietary, Lifestyle, Anthropometric, and Biochemical factors) of Study Participants (Continued)

\begin{tabular}{|c|c|c|c|c|c|c|c|}
\hline \multirow[t]{2}{*}{ Characteristic } & \multicolumn{2}{|l|}{ Total $(n=344)$} & \multicolumn{2}{|c|}{ Men $(n=172)$} & \multicolumn{2}{|c|}{ Women $(n=172)$} & \multirow[t]{2}{*}{$P$-value ${ }^{4}$} \\
\hline & $\mathrm{n}$ or mean or median & $\%$ or $\mathrm{SD}$ or $\mathrm{IQR}$ & $\mathrm{n}$ or mean & $\%$ or SD & $\mathrm{n}$ or mean & $\%$ or $\mathrm{SD}$ & \\
\hline Percent body fat & 30.9 & 7.9 & 27.8 & 6.9 & 34.0 & 7.6 & 0.000 \\
\hline \multicolumn{8}{|l|}{ Waist circumference } \\
\hline Low risk ${ }^{3}$ & 170 & 49.4 & 85 & 49.4 & 85 & 49.4 & 1 \\
\hline High risk & 174 & 50.6 & 87 & 50.6 & 87 & 50.6 & \\
\hline Vitamin D concentration ( $\mathrm{ng} / \mathrm{mL}$ ) & 25.7 & [18.2-25.7] & 28.4 & 15.0 & 28.1 & 12.8 & 0.846 \\
\hline
\end{tabular}

${ }^{1}$ Oral Contraceptive Pills

${ }^{2}$ Body Mass Index

${ }^{3}$ WC values were classified as high risk/low risk for diseases, using the World Health Organization (WHO) cutoffs for men $>102 \mathrm{~cm}$ and women $>88 \mathrm{~cm}[24]$

${ }^{4}$ The $P$ value reflects gender differences

Columns with superscripts without a common symbol differ, the $P$ value is $<0.05$

Comparisons of continuous and categorical variables were performed using independent sample T Test/Mann-Whitney-U-test and the chi square test /Fisher's

exact test, respectively

vitamin D status while controlling for the same factors in addition to alcohol intake and hypertriglyceridemia. However, the association was found to be of borderline significance $(p=0.054)$ (Table 4$)$.

\section{Discussion}

The current study showed that low vitamin D status was prevalent in Lebanese adults during fall, with more than 30 and $60 \%$ of participants having serum $25(\mathrm{OH}) \mathrm{D}$ concentrations $<20 \mathrm{ng} / \mathrm{mL}$ and $\leq 30 \mathrm{ng} / \mathrm{mL}$, respectively. $\mathrm{BMI}$ was not associated with vitamin D status; however PBF was associated with insufficient vitamin D status using the NOF cutoffs.

Low vitamin $\mathrm{D}$ status has become a major problem worldwide, even in sunny countries like Lebanon [27]. The prevalence of low vitamin $\mathrm{D}$ status reported in our study $(60 \%)$ was in line with the prevalence rates reported in neighboring countries ranging from $57.6 \%$ in Tehran [28] to up to $91 \%$ in Morocco [29]. The range of prevalence rates varied among studies due to the different study populations, education levels, season, BMI, age, body composition, gender, and cutoffs for vitamin D status. Our results were concordant with the prevalence rate of $73.3 \%$ among 105 Lebanese adults (aged > 18 years) visiting outpatient clinics between April and July reported by Rachkidi and Aoun, 2015 [6]. On the other hand, Gannage et al. 2014, reported a higher prevalence of $94.9 \%$ among employees in a university hospital $(n=329)$ [11]. In the latter study, data was collected over a year; accordingly, some participants were recruited in the winter season, which could increase the likelihood of low vitamin D status. The seasonal variation in vitamin $\mathrm{D}$ concentration has been previously reported in the literature [30]. Hoteit et al., 2014 reported that $25(\mathrm{OH}) \mathrm{D}$ concentrations were lower in the winter season $(20.1 \pm 9.2 \mathrm{ng} / \mathrm{mL})$ among 9147 Lebanese outpatients compared to $24.8 \pm 10.4 \mathrm{ng} / \mathrm{mL}$ in the fall season [5]. The mean serum 25(OH)D concentration reported in our study was $28.2 \pm 13.9 \mathrm{ng} / \mathrm{mL}$, which was similar to the mean reported by Hoteit et al., 2014 during the same season.

In our study, in bivariate analyses, longer duration of sun exposure was associated with better vitamin D status in the total sample and in men but not in women. Due to highly pigmented skin, individuals of Middle Eastern origin might need to spend more time in the

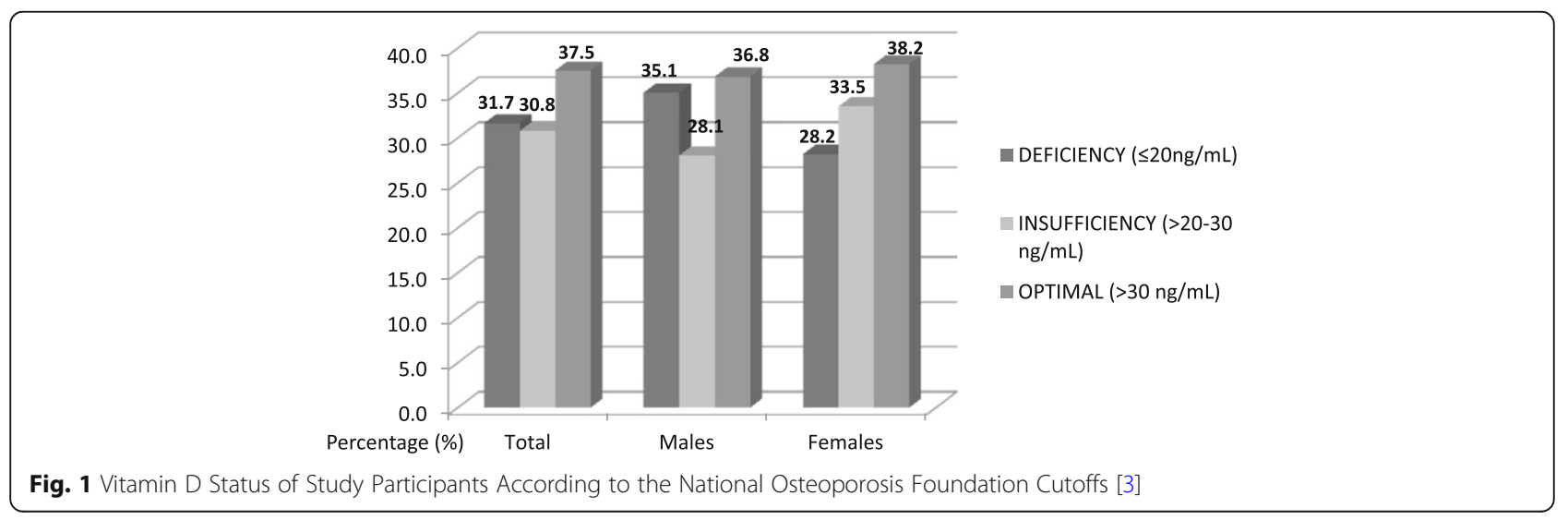




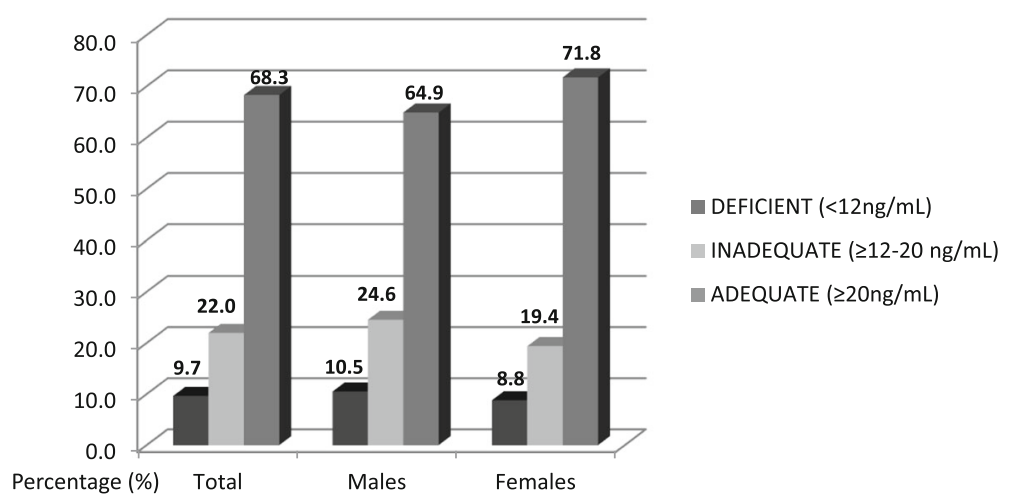

Fig. 2 Vitamin D Status of Study Participants According to the Institute of Medicine Cutoffs [2]

sun to synthesize sufficient amounts of vitamin D endogenously [31]. This justification is backed up by our multivariate logistic analyses; since sun exposure $>1 \mathrm{~h}$ was protective against low vitamin D status, while sun exposure between 16 and $60 \mathrm{~min}$ was not protective. It is likely we did not observe this association in women in bivariate analyses, since around $54 \%$ of women were using sunscreen, while only $4 \%$ of men were using sunscreen. It is well established in the literature that sunscreen use can block UVB light and reduce vitamin D synthesis significantly [32]. The association between sun exposure and vitamin D status is inconsistent in the literature, since several factors may affect the cutaneous synthesis and bioavailability of vitamin $\mathrm{D}$, such as the time of day, the use of sunscreen, and skin pigmentation $[6,32,33]$. These factors could explain gender differences in our sample.

In bivariate analyses, vitamin $\mathrm{D}$ intake was associated with vitamin D status in the total sample, and in women but not in men. Women who had a sufficient status had a higher vitamin D intake compared to women who had an insufficient status; this same trend was observed in men but did not reach statistical significance. Vitamin D is obtained from two sources, diet and sun exposure [1]. While sun exposure was not associated with vitamin D status in women due to the use of sunscreen, diet seems to be the most important factor affecting vitamin $\mathrm{D}$ status for women; however, the sun was the most important factor affecting vitamin D status for men [32]. However, in multivariate logistic regression, once all confounders were controlled for, sun exposure, vitamin $\mathrm{D}$ intake, and vitamin D supplements became protective against low status, which is concordant with the literature $[6,25,34]$.

Mean vitamin $\mathrm{D}$ intake $(2.2 \pm 3.2 \mu \mathrm{g} /$ day $)$ reported in our study was similar to that reported by Rachkidi and Aoun, $2015(2.05 \pm 1.69 \mu \mathrm{g} /$ day $)$. Both studies show low intakes of vitamin D compared to the DRI of $15 \mu \mathrm{g} /$ day
[35]. It is important to point out that vitamin D is found only in a few foods. Furthermore, the fortification of milk in Lebanon is not mandatory compared to other countries, such as the US and Canada [36]. In addition, the consumption of milk was low in our sample $(0.97 \pm$ 1.3 servings/day) which is below the recommendations set by the Lebanese Food-Based Dietary Guidelines of 3 cups/day [37]. Old evidence suggested a high prevalence of lactose intolerance in the Lebanese population; however, new evidence is lacking [38].

The association between alcohol intake and vitamin $\mathrm{D}$ status was observed in women only; this has been previously reported in the literature [39-41]. In our sample, women who drank alcohol had a higher prevalence of sufficient vitamin D status compared to non-drinkers. The relationship between alcohol intake and vitamin $\mathrm{D}$ status is not well understood, and results are still inconclusive. It is likely that this relationship is affected by confounders; especially that alcohol intake was not associated with vitamin D status in multivariable analyses.

Measures of adiposity, including WC and PBF, were inversely associated with vitamin D status in all participants and in both genders, while BMI was inversely associated with vitamin D status in women only. The association between BMI and vitamin D status is not always consistent in the literature [25], since BMI has many limitations, as it does not necessarily reflect the PBF [42]. The association of adiposity, measured by WC and PBF, with serum $25(\mathrm{OH}) \mathrm{D}$ is usually stronger than that with BMI [43]. In concordance with our results, multiple studies showed that vitamin D concentrations were significantly lower in both males and females with high risk WC compared to low risk categories $(p<0.05)$ $[9,11,17]$.

Our study found a positive association between low vitamin D status $(25(\mathrm{OH}) \mathrm{D} \leq 30 \mathrm{ng} / \mathrm{mL})$ and $\mathrm{PBF}$, which is also concordant with the literature [17, 25, 34, 44]. 
Table 2 Associations of socio-demographic, dietary, lifestyle, anthropometric factors with Vitamin D status ${ }^{*}$ among study participants

\begin{tabular}{|c|c|c|c|c|c|c|c|c|c|}
\hline \multirow[t]{3}{*}{ Characteristic } & \multicolumn{3}{|l|}{ Total $(n=268)$} & \multicolumn{3}{|c|}{ Men $(n=142)$} & \multicolumn{3}{|c|}{ Women $(n=126)$} \\
\hline & Insufficient & Sufficient & $P$-value ${ }^{3}$ & Insufficient & Sufficient & $P$-value ${ }^{3}$ & Insufficient & Sufficient & $P$-value ${ }^{3}$ \\
\hline & \multicolumn{3}{|c|}{ Mean \pm SD / n (\%)/ Median [IQR] } & \multicolumn{3}{|c|}{ Mean \pm SD / n (\%) } & \multicolumn{3}{|c|}{ Mean \pm SD / n (\%) } \\
\hline Age (years) & $40[33.0-51.0$ & $43[35.0-51.0]$ & 0.593 & $45.8 \pm 12.3$ & $42.1 \pm 11.2$ & 0.088 & $37.3 \pm 9.8$ & $39.3 \pm 9.7$ & 0.320 \\
\hline Marital status & & & 0.140 & & & 0.042 & & & 0.976 \\
\hline Single/Separated/ Divorced & $56(65.9)$ & $29(34.1)$ & & $23(57.5)$ & $17(42.5)$ & & $33(73.3)$ & $12(26.7)$ & \\
\hline Married & $138(75.4)$ & $45(24.6)$ & & $77(75.5)$ & $25(24.5)$ & & $61(75.3)$ & $20(24.7)$ & \\
\hline Education level & & & 0.793 & & & 0.551 & & & 0.231 \\
\hline High school & $45(70.3)$ & $19(29.7)$ & & $30(68.2)$ & $14(31.8)$ & & $15(75.0)$ & $5(25.0)$ & \\
\hline Bachelor degree & $52(75.4)$ & $17(24.6)$ & & $20(64.5)$ & $11(35.5)$ & & $32(84.2)$ & $6(15.8)$ & \\
\hline Graduate & $97(71.9)$ & $38(28.1)$ & & $50(74.6)$ & $17(25.4)$ & & $47(69.1)$ & $21(30.9)$ & \\
\hline Income (\$) & & & 0.902 & & & 0.137 & & & 0.295 \\
\hline$<2250$ & $68(70.8)$ & $28(29.2)$ & & $34(61.8)$ & $21(38.2)$ & & $34(82.9)$ & $7(17.1)$ & \\
\hline $2250-4000$ & $51(73.9)$ & $18(26.1)$ & & $23(82.1)$ & $5(17.9)$ & & $28(68.3)$ & $13(31.7)$ & \\
\hline$>4000$ & $75(72.8)$ & $28(27.2)$ & & $43(72.9)$ & $16(27.1)$ & & $32(72.7)$ & $12(27.3)$ & \\
\hline Vitamin D intake $(\mu \mathrm{g})$ & $1.9 \pm 2.0$ & $3.3 \pm 5.7$ & 0.047 & $2.2 \pm 2.2$ & $3.4 \pm 7.2$ & 0.290 & $1.6 \pm 1.7$ & $3.1 \pm 2.7$ & 0.006 \\
\hline Alcohol drinking & & & 0.095 & & & 0.964 & & & 0.022 \\
\hline No & $145(75.5)$ & $47(24.5)$ & & $64(71.1)$ & $26(28.9)$ & & $81(79.4)$ & $21(20.6)$ & \\
\hline Yes & $49(64.5)$ & $27(35.5)$ & & $36(69.2)$ & $16(30.8)$ & & $13(54.2)$ & $11(45.8)$ & \\
\hline Smoking & & & 0.563 & & & 1 & & & 0.480 \\
\hline No & $122(73.9)$ & $43(26.1)$ & & $55(70.5)$ & $23(29.5)$ & & $67(77.0)$ & $20(23.0)$ & \\
\hline Yes & $72(69.9)$ & $31(30.1)$ & & $45(70.3)$ & $19(29.7)$ & & $27(69.2)$ & $12(30.8)$ & \\
\hline Daily exposure to direct sunlight & & & 0.005 & & & 0.028 & & & 0.206 \\
\hline$\leq 15$ mins & $81(78.6)^{a}$ & $22(21.4)^{a}$ & & $43(79.6)^{a}$ & $11(20.4)^{a}$ & & $38(77.6)$ & $11(22.4)$ & \\
\hline $16-60 \mathrm{~min}$ & $64(78.0)^{\mathrm{a}}$ & $18(22.0)^{\mathrm{a}}$ & & $26(76.5)^{a, b}$ & $8(23.5)^{a, b}$ & & $38(79.2)$ & $10(20.8)$ & \\
\hline$>60$ mins & $49(59.0)^{b}$ & $34(41.0)^{b}$ & & $31(57.4)^{b}$ & $23(42.6)^{b}$ & & $18(62.1)$ & $11(37.9)$ & \\
\hline Use sunscreen & & & 0.744 & & & 0.670 & & & 0.185 \\
\hline No & $142(73.2)$ & $52(26.8)$ & & $95(69.9)$ & $41(30.1)$ & & $47(81.0)$ & $11(19.0)$ & \\
\hline Yes & $52(70.3)$ & $22(29.7)$ & & $5(83.3)$ & $1(16.7)$ & & $47(69.1)$ & $21(30.9)$ & \\
\hline $\mathrm{BMI}{ }^{1}\left(\mathrm{Kg} / \mathrm{m}^{2}\right)$ & & & 0.242 & & & 0.479 & & & 0.008 \\
\hline Underweight & $0(0.0)$ & $0(0.0)$ & & $0(0.0)$ & $0(0.0)$ & & $0(0.0)$ & $0(0.0)$ & \\
\hline Normal & $68(68.0)$ & $32(32.0)$ & & $20(76.9)$ & $6(23.1)$ & & $48(64.9)^{\mathrm{b}}$ & $26(35.1)^{\mathrm{a}}$ & \\
\hline Overweight & $71(71.7)$ & $28(28.3)$ & & $44(65.7)$ & $23(34.3)$ & & $27(84.4)^{\mathrm{a}}$ & $5(15.6)^{a}$ & \\
\hline Obese & $55(79.7)$ & $14(20.3)$ & & $36(73.5)$ & $13(26.5)$ & & $19(95.0)^{b}$ & $1(5.0)^{\mathrm{a}}$ & \\
\hline Percent body fat & $31.2 \pm 7.5$ & $27.2 \pm 7.5$ & 0.000 & $28.3 \pm 6.6$ & $25.6 \pm 7.5$ & 0.039 & $34.4 \pm 7.0$ & $29.3 \pm 7.0$ & 0.001 \\
\hline Waist circumference risky & & & 0.012 & & & 0.581 & & & 0.003 \\
\hline No & $88(65.2)$ & $47(34.8)$ & & $48(67.6)$ & $23(32.4)$ & & $40(62.5)$ & $24(37.5)$ & \\
\hline Yes $^{2}$ & $106(79.7)$ & $27(20.3)$ & & $52(73.2)$ & $19(26.8)$ & & $54(87.1)$ & $8(12.9)$ & \\
\hline
\end{tabular}

"The National Osteoporosis Foundation cutoffs were used to define vitamin D status (Sufficient: 25 hydroxyvitamin D $>30 \mathrm{ng} / \mathrm{mL}$ and Insufficient: 25 hydroxyvitamin $\mathrm{D} \leq 30 \mathrm{ng} / \mathrm{mL}$ )

*Participants taking vitamin D supplements were excluded $(n=75)$

'Body Mass Index

${ }^{2}<88 \mathrm{~cm}$ for women and $<102 \mathrm{~cm}$ for men [24]

${ }^{3}$ The $P$ value reflects differences in vitamin $D$ status

Columns with superscripts without a common symbol differ, the $P$ value is $<0.05$

Comparisons of continuous and categorical variables were performed using independent sample T Test/Mann-Whitney-U-test and the chi square test /Fisher's exact test, respectively 
Table 3 Multivariable logistic regression for body composition and Vitamin D Status ( $\leq 30 \mathrm{ng} / \mathrm{mL}$ ) among study participants ${ }^{*}$

\begin{tabular}{|c|c|c|c|c|}
\hline \multirow[t]{2}{*}{ Characteristic } & \multirow{2}{*}{$\begin{array}{l}\text { Odds } \\
\text { Ratio } \\
\text { (OR) }\end{array}$} & \multicolumn{2}{|l|}{$95 \%$ C.I } & \multirow[t]{2}{*}{$P$ value } \\
\hline & & Lower & Upper & \\
\hline Percent Body Fat & 1.077 & 1.012 & 1.145 & 0.019 \\
\hline $\mathrm{BMI} \mathrm{l}^{1}\left(\mathrm{~kg} / \mathrm{m}^{2}\right)$ & 0.969 & 0.881 & 1.066 & 0.521 \\
\hline Age & 0.976 & 0.950 & 1.004 & 0.092 \\
\hline Gender & 0.568 & 0.227 & 1.419 & 0.226 \\
\hline \multicolumn{5}{|l|}{ Education } \\
\hline Bachelor degree * High School & 1.007 & 0.455 & 2.229 & 0.986 \\
\hline Graduate ${ }^{*}$ High School & 1.059 & 0.523 & 2.145 & 0.874 \\
\hline Sunscreen Use & 0.827 & 0.415 & 1.651 & 0.591 \\
\hline Chronic Disease & 1.478 & 0.799 & 2.735 & 0.213 \\
\hline Vitamin D intake $(\mu \mathrm{g})$ & 0.837 & 0.746 & 0.941 & 0.003 \\
\hline \multicolumn{5}{|l|}{ Sun Exposure } \\
\hline $16-60 \min * \leq 15 \operatorname{mins}$ & 1.271 & 0.670 & 2.413 & 0.463 \\
\hline$>60$ mins $^{*} \leq 15$ mins & 0.485 & 0.258 & 0.912 & 0.025 \\
\hline Use of $O C P^{2}$ & 0.346 & 0.019 & 6.154 & 0.470 \\
\hline Vitamin D supplements & 0.084 & 0.042 & 0.169 & 0.000 \\
\hline \multicolumn{5}{|c|}{$\begin{array}{l}\text { "The National Osteoporosis Foundation cutoffs were used to define vitamin D } \\
\text { status (Sufficient: } 25 \text { hydroxyvitamin } D>30 \mathrm{ng} / \mathrm{mL} \text { and Insufficient: } 25 \\
\text { hydroxyvitamin } D \leq 30 \mathrm{ng} / \mathrm{mL} \text { ) } \\
\text { 'Body Mass Index } \\
{ }^{2} \text { Oral Contraceptive Pills }\end{array}$} \\
\hline
\end{tabular}

While this relationship is not fully understood, it is assumed that since vitamin D is a fat soluble vitamin, it might be sequestered in the excess adipose tissue of obese adults and would be slowly released at negative energy balance [17]. Further, a potential confounder is that obesity is also linked to an unhealthy lifestyle, characterized by less physical activity, less sun exposure and, hence, lower vitamin D concentrations [45].

Using the IOM cutoffs to define vitamin D status as inadequate $(25(\mathrm{OH}) \mathrm{D}<20 \mathrm{ng} / \mathrm{mL})$ the association between vitamin D status and PBF was observed but did not reach statistical significance $(p>0.05)$. It is possible that the association between vitamin D status and body composition is not observed unless vitamin $\mathrm{D}$ concentrations are high, since NOF cutoffs are higher than IOM cutoffs [2, 3].

The present study has some limitations that need to be acknowledged. First, the study design was cross-sectional, which does not allow drawing causal relationships between vitamin $\mathrm{D}$ status and measures of adiposity [46]. Second, the study was performed on employees from a private university in Lebanon, which limits generalizability to the Lebanese population. In addition, BIA was used for the assessment of body composition. The dual-energy x-ray absorptiometry (DEXA), computed tomography (CT), and magnetic resonance
Table 4 Multivariable logistic regression for body composition and Vitamin D status $(<20 \mathrm{ng} / \mathrm{mL})$ among study participants*

\begin{tabular}{|c|c|c|c|c|}
\hline \multirow[t]{2}{*}{ Characteristic } & \multirow{2}{*}{$\begin{array}{l}\text { Odds } \\
\text { Ratio } \\
\text { (OR) }\end{array}$} & \multicolumn{2}{|c|}{$95 \%$ C.I } & \multirow[t]{2}{*}{$P$ value } \\
\hline & & Lower & Upper & \\
\hline Percent Body Fat & 1.062 & 0.999 & 1.130 & 0.054 \\
\hline $\mathrm{BMI} \mathrm{l}^{1}\left(\mathrm{~kg} / \mathrm{m}^{2}\right)$ & 0.935 & 0.854 & 1.024 & 0.148 \\
\hline Age & 0.972 & 0.944 & 1.000 & 0.049 \\
\hline Gender & 0.466 & 0.188 & 1.157 & 0.1 \\
\hline \multicolumn{5}{|l|}{ Education } \\
\hline Bachelor degree * High School & 0.951 & 0.442 & 2.045 & 0.897 \\
\hline Graduate * High School & 1.113 & 0.559 & 2.214 & 0.761 \\
\hline Sunscreen Use & 0.578 & 0.286 & 1.167 & 0.126 \\
\hline Chronic Disease & 1.036 & 0.552 & 1.941 & 0.913 \\
\hline Vitamin D Intake $(\mu \mathrm{g})$ & 0.829 & 0.717 & 0.958 & 0.011 \\
\hline \multicolumn{5}{|l|}{ Sun Exposure } \\
\hline $16-60 \mathrm{~min}^{*} \leq 15 \mathrm{mins}$ & 0.914 & 0.492 & 1.698 & 0.776 \\
\hline$>60$ mins $^{*} \leq 15$ mins & 0.747 & 0.396 & 1.412 & 0.370 \\
\hline Use of $O C P^{2}$ & 2.140 & 0.122 & 37.443 & 0.602 \\
\hline Vitamin D Supplements & 0.131 & 0.052 & 0.333 & 0.000 \\
\hline Alcohol Intake & 0.422 & 0.222 & 0.801 & 0.008 \\
\hline Hypertriglyceridemia $^{3}$ & 2.189 & 1.153 & 4.157 & 0.017 \\
\hline
\end{tabular}

"The Institute of Medicine cutoffs were used to define vitamin $D$ status (Adequate: 25 hydroxyvitamin $\mathrm{D} \geq 20 \mathrm{ng} / \mathrm{mL}$ and Inadequate: 25 hydroxyvitamin $\mathrm{D}<20 \mathrm{ng} / \mathrm{mL}$ )

'Body Mass Index

${ }^{2}$ Oral Contraceptive Pills

${ }^{3} \geq 150 \mathrm{mg} / \mathrm{dL}$ [48]

imaging (MRI) are considered the gold standard imaging modality for the precise estimation of amount of adipose tissue in various body regions [16]. However, DEXA, CT and MRI imaging are impractical for screening the general population, since they are expensive and invasive [34]. For the assessment of vitamin D concentration, ELISA, the most commonly used technique, was used, since it is simple and inexpensive, yet it is less reliable than the gold standard technique, HPLC. HPLC is not commonly used because of its complexity and limitations including the need for specialized staff, the large volume of blood required, and the longer turnaround time [47]. Data was collected between mid-October to mid-December, which means that we cannot compare our results to studies performed in different seasons. Vitamin D content of many foods listed in the FFQ were not available in the Lebanese food composition tables; instead, the Canadian Nutrient File was used to estimate the vitamin D content of these foods.

To our knowledge, it is the first study in Lebanon to assess the association between body composition and vitamin D status, while controlling for BMI and other important confounders [18]. 


\section{Conclusion}

Our results support our hypothesis confirming that PBF is positively associated with low vitamin D status independent of BMI in our sample of university employees. Accordingly, education about the importance of consuming high sources of vitamin $\mathrm{D}$ is primordial, particularly since living in a sunny country might undermine the need to focus on diet, as Lebanese might believe that sun exposure is sufficient to maintain healthy vitamin D status. Further, this study reinforces the need for regular screening for low vitamin D status in Lebanese adults, particularly among individuals at risk, including those with high risk WC, high PBF, who work indoors, and have low vitamin $\mathrm{D}$ intake, and recommending vitamin $\mathrm{D}$ supplementation if needed. As low vitamin D status has been recently associated with many chronic diseases, a nationwide assessment of vitamin D status is required among different age and gender groups across different seasons to identify whether the government needs to consider the fortification of milk at the national level.

Moreover, cohort studies examining the association between body fat and vitamin $\mathrm{D}$ are needed to address the temporal relationship with vitamin D status.

\section{Abbreviations}

AGS: American Geriatrics Society; BIA: Bioelectrical impedance analysis; BMI: Body mass index; CT: Computed tomography; DEXA: Dual-energy X-ray absorptiometry; ELISA: Enzyme linked immunosorbent assay; FFQ: Food frequency questionnaire; IOM: Institute of Medicine; IPAQ: International physical activity questionnaire; LDL: Low density lipoprotein; MRI: Magnetic resonance imaging; NDU: Notre Dame University; NOF: National Osteoporosis Foundation; OCP: Oral contraceptive pills; PBF: Percent body fat; SPSS: Statistical Package for Social Sciences; WC: Waist circumference; WHO: World Health Organization

\section{Acknowledgements \\ The authors would like to thank the participants of this study for being generous with their time. In addition, the authors are grateful for the assistance of Ms. Samar Merhi, Ms. Najwa El Gerges, Ms. Micheline Abou Saleh and Ms. Marie Kosseify for their help with measurements of the biochemical variables, the two nutritionists, Ms. Helen Obeid and Ms. Mira Fatayri for their efforts in data collection, Ms. Maya Abou Jaoude for her help in the management of dietary data, and Dr. Doris Jaalouk for her input in the development of study questionnaires and data management. The authors would like to thank Mrs. Karen Doerr for proofreading and editing the manuscript.}

\section{Availability of data and materials}

Data and all other materials for this study are kept at Notre Dame University, Zouk Mosbeh campus. The datasets generated and analyzed during the study are not publicly available due the terms of consent to which the participants agreed but are available in anonymized form from the corresponding author on reasonable request.

\section{Authors' contributions}

SAH, JBM, RG and JEHF conceived the study and developed the study design and methods. SAH and RG conducted the data collection, entered and analyzed the data. SAH interpreted the data and drafted the manuscript. JBM and JEHF critically reviewed the manuscript. All authors read and approved the final manuscript.

\section{Ethics approval and consent to participate}

Prior to the initiation of the study, the study protocol was approved by the Institutional Review Board of Notre Dame University. Those who agreed to participate were asked to sign an informed consent form. No financial or other incentives were offered.

\section{Consent for publication}

Not applicable.

Competing interests

The authors declare that they have no competing interests.

\section{Publisher's Note}

Springer Nature remains neutral with regard to jurisdictional claims in published maps and institutional affiliations.

\section{Author details}

${ }^{1}$ Department of Dietetics and Nutrition, The University of Kansas Medical Center, 3901 Rainbow Blvd, Kansas City, KS 66160, USA. ²Department of Nursing and Health Sciences, Notre Dame University- Louaize (NDU), Zouk Mosbeh, Lebanon. ${ }^{3}$ Department of Endocrinology, Diabetes, Metabolism and Eating Disorders, University Hospital of Saint-Etienne, Saint-Etienne Cedex, France.

Received: 23 April 2018 Accepted: 29 June 2018

Published online: 26 July 2018

\section{References}

1. Chen TC, Chimeh F, Lu Z, Mathieu J, Person KS, Zhang A, et al. Factors that influence the cutaneous synthesis and dietary sources of vitamin D. Arch Biochem Biophys. 2007;460(2):213-7.

2. Ross AC, Manson JE, Abrams SA, Aloia JF, Brannon PM, Clinton SK, et al. The 2011 report on dietary reference intakes for calcium and vitamin D from the institute of medicine: what clinicians need to know. J Clin Endocrinol Metab. 2011;96(1):53-8.

3. Holick MF, Binkley NC, Bischoff-Ferrari HA, Gordon CM, Hanley DA, Heaney $\mathrm{RP}$, et al. Evaluation, treatment, and prevention of vitamin D deficiency: an endocrine society clinical practice guideline. J Clin Endocrinol Metab. 2011; 96(7):1911-30

4. Mithal A, Wahl DA, Bonjour JP, Burckhardt P, Dawson-Hughes B, Eisman JA, et al. Global vitamin D status and determinants of hypovitaminosis D. Osteoporos Int. 2009;20(11):1807-20.

5. Hoteit M, Al-Shaar L, Yazbeck C, Sleiman MB, Ghalayini T, Fuleihan GE. Hypovitaminosis D in a sunny country: time trends, predictors, and implications for practice guidelines. Metabolism. 2014;63(7):968-78.

6. Rachkidi D, Aoun A. Vitamin D status and determinants among ambulatory patients: a cross-sectional study. Clin Nutr. 2014;33(1):14.

7. Florez H, Martinez R, Chacra W, Strickman-Stein N, Levis S. Outdoor exercise reduces the risk of hypovitaminosis $D$ in the obese. J Steroid Biochem Mol Biol. 2007:103(3):679-81.

8. Vanlint S. Vitamin D and obesity. Nutrients. 2013;5(3):949-56.

9. Dahbani K, Tsulidis KK, Murphy N, Ward HA, Bliott P, Riboli E, et al. Prevalence of vitamin D deficiency and association with metabolic syndrome in Qatari population. Nutr Diabetes. 2017;7:e263.

10. Sadiya A, Ahmed A, Skaria S, Abusnana S. Vitamin D status and its relationship with metabolic markers in persons with obesity and type 2 diabetes in the UAE: a cross-sectional study. J Diabetes Res. 2014;2014. https://doi.org/10.1155/2014/869307.

11. Gannagé-Yared MH, Helou E, Zaraket $V$, et al. Serum 25 hydroxyviamin D in employees of a middle eastern university hospital. J Endocrinol Investig. 2014:37:541.

12. Fuleihan G. Vitamin D deficiency in the Middle East and its health consequences. In: Holick MF vitamin D: physiology, molecular biology, and clinical applications. 2nd ed. New Jersey: Humana Press; 2009.

13. Golbahar J, Al-Saffar N, Altayab Diab D, Al-Othman S, Darwish A, Al-Kafaji G. Predictors of vitamin D deficiency and insufficiency in adult Bahrainis: a crosssectional study. Public Health Nutr. 2014;17(4):732-8

14. Gannage-Yared MH, Chedid R, Khalife S, Azzi E, Zoghbi F, Halaby G. Vitamin $D$ in relation to metabolic risk factors, insulin sensitivity and adiponectin in a young middle-eastern population. Eur J Endocrinol. 2009:160(6):965-71.

15. Andreozzi P, Verrusio W, Viscogliosi G, Summa ML, Gueli N, Cacciafesta M, et al. Relationship between vitamin D and body fat distribution evaluated by DXA in postmenopausal women. Nutrition. 2016;32(6):687-92. 
16. Kim D, Kim J. Association between serum 25-hydroxyvitamin D levels and adiposity measurements in the general korean population. Nutr Res Pract. 2016;10(2):206-11.

17. González L, Ramos-Trautmann G, Díaz-Luquis GM, Pérez CM, Palacios C. Vitamin D status is inversely associated with obesity in a clinic-based sample in Puerto Rico. Nutr Res. 2015;35(4):287-93.

18. Bassil D, Rahme M, Hoteit M, Fuleihan G. Hypovitaminosis D in the Middle East and North Africa: prevalence, risk factors and impact on outcomes. Dermatoendocrinol. 2013;5(2):274-98.

19. Booth M. Assessment of physical activity: an international perspective. Res $Q$ Exerc Sport. 2000;71(2):114-20

20. El Hayek J, Pham T, Finch S, Hazell T, Vanstone C, Weiler H. Validity and reproducibility of a short food frequency questionnaire in assessing calcium and vitamin D intake in Canadian preschoolers. EC Nutr. 2014;1(1):9-18.

21. Block G, Coyle LM, Hartman AM, Scoppa SM. Revision of dietary analysis software for the health habits and history questionnaire. Am J Clin Nutr. 1994;139(12):1190-6.

22. Pellet $P$, Shadarevian $S$. Food composition tables for use in the middle east. 2nd ed; 1970.

23. Government of Canada. Canadian nutrient file 2016. https://food-nutrition. canada.ca/cnf-fce/index-eng.jsp. Accessed Jan 2018.

24. WHO. Waist circumference and waist-hip ratio. Report of a WHO expert consultation. Geneva: World Health Organization; 2008. p. 8-11.

25. Shantavasinkul PC, Phanachet P, Puchaiwattananon O, Chailurkit $L$, Lepananon T, Chanprasertyotin S, et al. Vitamin D status is a determinant of skeletal muscle mass in obesity according to body fat percentage. Nutrition. 2015;31(6):801-6.

26. Baracos V, Caserotti P, Earthman CP, Fields D, Gallagher D, Hall KD, et al. Advances in the science and application of body composition measurement. JPEN. 2012;36(1):96-107.

27. Gannagé-Yared MH, Chemali R, Yaacoub N, Halaby G. Hypovitaminosis D in a sunny country: relation to lifestyle and bone markers. JBMR. 2000;15(9): 1856-62.

28. Hashemipour S, Larijani B, Adibi H, Javadi E, Sedaghat M, Pajouhi M, et al. Vitamin $D$ deficiency and causative factors in the population of Tehran. BMC Public Health. 2004;4(1):38.

29. Allali F, El Aichaoui S, Khazani H, Benyahia B, Saoud B, El Kabbaj S, et al. High prevalence of hypovitaminosis D in Morocco: relationship to lifestyle, physical performance, bone markers, and bone mineral density. Semin Arthritis Rheum. 2009;38(6):444-51.

30. Bolland MJ, Grey AB, Ames RW, Mason BH, Horne AM, Gamble GD, et al. The effects of seasonal variation of 25-hydroxyvitamin $D$ and fat mass on a diagnosis of vitamin D sufficiency. Am J Clin Nutr. 2007;86(4):959-64.

31. Hagenau T, Vest R, Gissel T, Poulsen C, Erlandsen M, Mosekilde L, et al. Global vitamin $D$ levels in relation to age, gender, skin pigmentation and latitude: an ecologic meta-regression analysis. Osteoporos Int. 2009;20(1):133.

32. Matsuoka LY, Wortsman J, Hollis BW. Use of topical sunscreen for the evaluation of regional synthesis of vitamin D3. J Am Acad Dermatol. 1990; 22(5:772-5.

33. Harris SS, Dawson-Hughes B. Reduced sun exposure does not explain the inverse association of 25-hydroxyvitamin D with percent body fat in older adults. J Clin Endocrinol Metab. 2007;92(8):3155-7.

34. Savastano S, Barrea L, Savanelli MC, Nappi F, Di Somma C, Orio F, et al. Low vitamin D status and obesity: role of nutritionist. Rev Endocr Metab Disord. 2017;18(2):215-25.

35. Institute of Medicine. Dietary reference intakes for calcium and vitamin D. Washington, DC: National Academies Press; 2011. In Press

36. Calvo MS, Whiting SJ, Barton CN. Vitamin D fortification in the United States and Canada: current status and data needs. Am J Clin Nutr. 2004;80(6): 1710-6.

37. Hwalla N, Nasreddine L, Jarjar AF. The food-based dietary guideline manual for promoting healthy eating in the Lebanese adult population. The American University of Beirut. 2013.

38. Nasrallah SM. Lactose intolerance in the lebanese population and in mediterranean lymphoma. Am J Clin Nutr. 1979;32(10):1994-6.

39. Jacques PF, Felson DT, Tucker KL, Mahnken B, Wilson PW, Rosenberg $\mathbb{H}_{\text {, }}$ et al. Plasma 25-hydroxyvitamin D and its determinants in an elderly population sample. Am J Clin Nutr. 1997;66(4):929-36.

40. Lee K. Sex-specific relationships between alcohol consumption and vitamin D levels: the Korea national health and nutrition examination survey 2009. Nutr Res Pract. 2012;6(1):86-90.
41. McCullough ML, Weinstein SJ, Freedman DM, Helzlsouer K, Flanders WD, Koenig K, et al. Correlates of circulating 25-hydroxyvitamin D: cohort consortium vitamin D pooling project of rarer cancers. Am J Epidemiol. 2010:172(1):21-35

42. Ode JJ, Pivarnik JM, Reeves MJ, Knous JL. Body mass index as a predictor of percent fat in college athletes and nonathletes. Med Sci Sports Exerc. 2007; 39(3):403-9.

43. Arunabh S, Pollack S, Yeh J, Aloia JF. Body fat content and 25hydroxyvitamin D levels in healthy women. J Clin Endocrinol Metab. 2003; 88(1):157-61.

44. Parikh SJ, Edelman M, Uwaifo Gl, Freedman RJ, Semega-Janneh M, Reynolds J, et al. The relationship between obesity and serum 1, 25-dihydroxy vitamin D concentrations in healthy adults. J Clin Endocrinol Metab. 2004;89(3):1196-9.

45. Osei K. 25-OH vitamin D: is it the universal panacea for metabolic syndrome and type 2 diabetes? J Clin Endocrinol Metab. 2010;95(9):4220-2.

46. Aasheim ET, Hofso D, Hjelmesaeth J, Birkeland Kl, Bohmer T. Vitamin status in morbidly obese patients: a cross-sectional study. Am J Clin Nutr. 2008; 87(2):362-9.

47. Wallace AM, Gibson S, de la Hunty A, Lamberg-Allardt C, Ashwell M. Measurement of 25-hydroxyvitamin D in the clinical laboratory: current procedures, performance characteristics and limitations. Steroids. 2010;75(7): 477-88.

48. Huang PL. A comprehensive definition of metabolic syndrome. Dis Model Mech. 2009;2(5-6):231-7.

\section{Ready to submit your research? Choose BMC and benefit from:}

- fast, convenient online submission

- thorough peer review by experienced researchers in your field

- rapid publication on acceptance

- support for research data, including large and complex data types

- gold Open Access which fosters wider collaboration and increased citations

- maximum visibility for your research: over $100 \mathrm{M}$ website views per year

At BMC, research is always in progress.

Learn more biomedcentral.com/submissions 